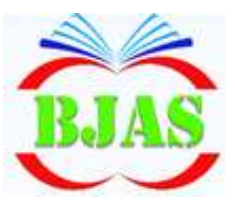

ISSN $1814-5868$
Available online at http://bajas.edu.iq

https://doi.org/10.37077/25200860.2021.34.2.07

College of Agriculture, University of Basrah

Basrah J. Agric. Sci., 34(2): 88-99, 2021
Basrah Journal

of Agricultural

Sciences

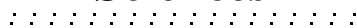

E-ISSN: 2520-0860

\title{
Effect of Hammer Shape and Impact Area on Hammer Mill Performance under Different Feed Rates
}

\author{
Assad Y. Khudher*, Salim A. Almaliki ${ }^{1}$ \& Majed S. Himoud ${ }^{2}$ \\ Department of Agricultural Machines and Equipment, College of Agriculture, University of \\ Basrah, Iraq \\ *Corresponding author-mail: assad.khudher@uobasrah.edu.iq; ${ }^{1}$ Salim.Bander@uobasrah.edu.iq; \\ ${ }^{2}$ majed.himoud@uobasrah.edu.iq \\ Received 12 ${ }^{\text {th }}$ November 2020; Accepted 25 ${ }^{\text {th }}$ April 2021; Available online 2 November 2021
}

\begin{abstract}
The research aims to compare the performance (PC) and specific energy consumption (Spc.) of the hammer mill when using the T-hammer against the (traditional) rectangular hammer. A homemade mill with four hammers was used in experiment. 36 treatments: 2 hammer shape x 3 impact area $\left(840,720\right.$ and $\left.960 \mathrm{~mm}^{2}\right)$ x 2 feeding rates (1500 and $\left.3000 \mathrm{~g} \mathrm{~min}^{-1}\right)$ x 3 replicates, with completely random design. The results showed that there was no significant effect of hammer shape on $\mathrm{PC}$ at the feed rate of $3000 \mathrm{~g} \mathrm{~min}^{-1}$, while there was an effect at the rate of $1500 \mathrm{~g}$ $\mathrm{min}^{-1}$. An effect was also found for the impact area on the PC at both feeding rates and on Spc., as an inverse relationship appeared between the impact area and mill productivity at the feed rate $1500 \mathrm{~g} \mathrm{~min}^{-1}$. The area of $720 \mathrm{~mm}^{2}$ surpassed the area 480 and $960 \mathrm{~mm}^{2}$ at the rate of feeding $3000 \mathrm{~g} \mathrm{~min}^{-1}$, as it recorded $1215.65 \mathrm{~g} \mathrm{~min}^{-1}$ compared to 950.65 and $882.65 \mathrm{~g} \mathrm{~min}^{-1}$, respectively. There is effect of feeding rate on PC and Spc. The traditional hammer is recommended for simplicity of design, manufacture and performance at high feed rates compared to the T-shaped hammer.
\end{abstract}

Keywords: Grinding, Impact energy, mill capacity, Specific energy consumption, mill blade, flow rate.

\section{Introduction}

Hammer milling machines are widely used in agrarian fields and animal feed plants because of their ability to pound materials in different degrees (coarse, medium and fine). The machine's basic operation was based on the collision force (mechanical impact force) decreasing the size of the materials (Djuro et al., 2016). Grinding is important processes and energy-intensive processes in the feed industry, accounting for $71 \%$ of total power consumption during feed processing (Shirshaab \& Jassim, 2021). Grinding energy requirements are determined by the kinematical and geometrical parameters of the grinding machine, as well as the physical properties of the ground material (Dabbour et al., 2015). The hammer is the most important component of the crusher. The type, shape, and characteristics of the hammer have a significant impact on the grinder's output. The rectangular mallet is the most well-known hammer shape used in the hammer unit (traditional). Ali et al. (2019) conducted research in which he replaced rectangular 
mallets with steel rings (new hammer) and discovered a reduction in energy consumption due to the new hammer's lighter weight as compared to the rectangular hammer. When a new hammer form (a triangle with an inclination of 45 degrees from the horizontal plane perpendicular to the mill's rotation axis) was used instead of inclined hammers at angles of 0,35 , and 55 degrees, MirceaValentin et al. (2013) observed an increase in mill productivity and a decrease in real energy consumption. Satoshi et al. (2004) investigated the effect of hammer styles by cutting the edge of the hammer at different angles ranging from 15 to 30 degrees and discovered that milling efficiency improved. The highest efficiency was achieved with the lowest level of energy requirements by using the highest feed rate of $120 \mathrm{~kg} \cdot \mathrm{hr}^{-1}$ with various velocities and diameter of sieve holes, according to a study conducted using three levels of feed rate 60,90 , and $120 \mathrm{~kg}$. $\mathrm{hr}^{-1}$ with various velocities and diameter of sieve holes (Ibrahim et al., 2019). The effective work surface area may not be utilized due to insufficient power transfer to the hammer and consequently, the performance of the mill will be reduced (Heimann, 2019).

Due to the variety of hammer shapes used in hammer mills. It makes the concerned people have difficulty choosing a particular shape in the mills. Therefore, the present study was conducted to compare the performance of hammer shape ( $\mathrm{T}$ - shape versus rectangle shape) and the effective surface area under two mill feeding rates.

\section{Materials \& Methods}

A small local mill was built with the specifications mentioned in table (1). To guide an investigation and crush yellow corn kernels. A strainer was used to clean the grains of contaminants, and the moisture content was calculated using the wet weight of 10.4 percent (Oluwole et al., 2019). The effect of hammer shape, impact area and interference was studied using a feed rate of 1500 and $3000 \mathrm{~g} \mathrm{~min}^{-1}$. The experiment was carried out according to a fully randomized design with three replications for each treatment. Analyze the results using the spss $23_{2}$ program.

Table (1) : Specifications of the locally grain mill.

\begin{tabular}{|c|c|c|c|}
\hline Parameters & Value, unit & Parameters & Value, unit \\
\hline 4 Blades ( Iron) & $\begin{array}{c}\text { Total length } 100 \mathrm{~mm} \\
\text { Effective length } 80 \\
\mathrm{~mm}\end{array}$ & $\begin{array}{c}\text { Ground grain exit height } \\
\text { off the floor }\end{array}$ & $70 \mathrm{~cm}$ \\
\hline Blade weight & $* 98 \pm 2 \mathrm{~g}$ & $\begin{array}{c}\text { Power engine (Electrical } \\
\text { Motor- single phase) }\end{array}$ & $\begin{array}{c}2 \mathrm{HP}(1.5 \mathrm{KW}), \\
220 \mathrm{~V}, 9.3 \mathrm{~A}\end{array}$ \\
\hline Screen Opening & $6 \mathrm{~mm}$ & Engine pulley- diameter & $10 \mathrm{~cm}$ \\
\hline Total screen area & $\begin{array}{c}12800 \mathrm{~mm}^{2} \\
(16 \mathrm{~cm} \times 8 \mathrm{~cm})\end{array}$ & Engine velocity & $2830 \mathrm{RPM}$ \\
\hline Grinder - case diameter & $30 \mathrm{~cm}$ & Grinder pulley- diameter & $8 \mathrm{~cm}$ \\
\hline Grinder - effective diameter & $27 \mathrm{~cm}$ & Grinder velocity & $2264 \mathrm{RPM}$ \\
\hline Hammer disk- diameter & $10 \mathrm{~cm}$ & ---- & --- \\
\hline
\end{tabular}




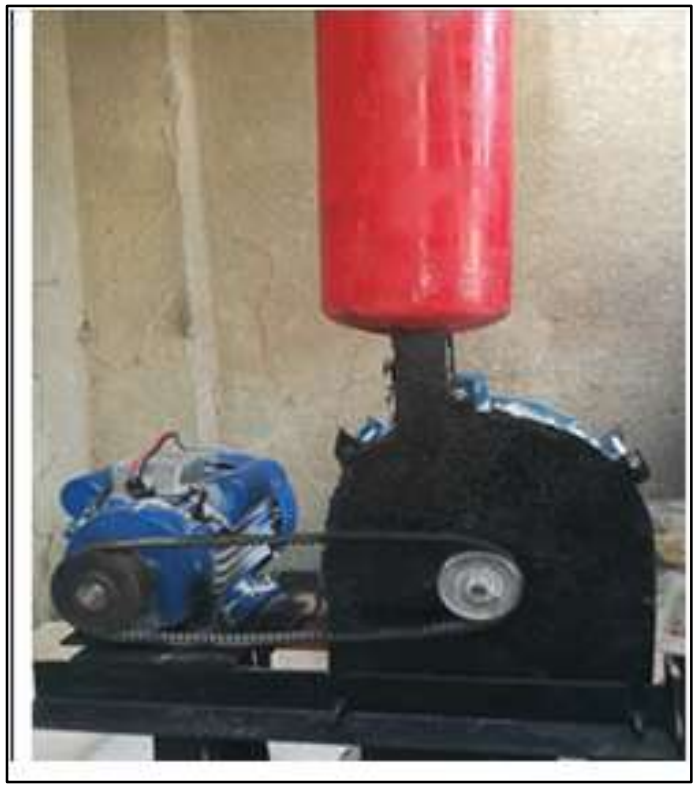

Fig. (1): Hammer mill.

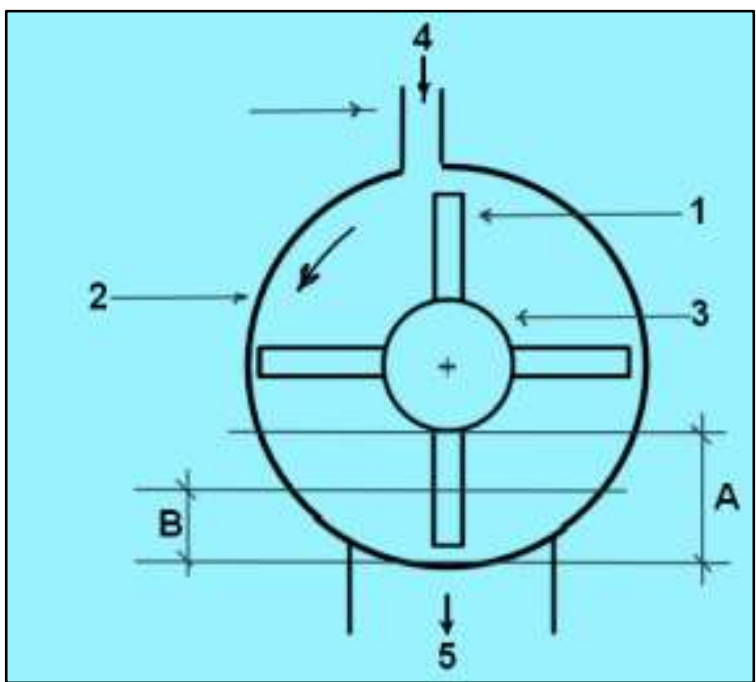

Fig. (2): Description of mill parts and feed.

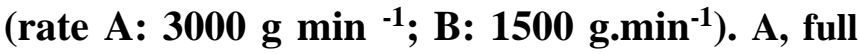
explotion of impact area $B$, incomplete explotion 1blade 2- room of milling 3- hammer dick 4- gate, 5exit hole.

b , hammer's thickness ; L, hammer's length

A feeding rate: A gate in the passage connecting the tank and the top of the mill was used to monitor grain descent into the grinding chamber. During the specified operating time, the gate opening was changed to drop the grains according to the feeding rate 1500 and 3000 g. $\mathrm{min}^{-1}$ (Dabbour et al., 2015). The below fig. (2) clarify that.

\section{Studied factors}

1- Hammer's shape is two levels, a- The Traditional hammer (Fig. 3a) and b- the Tshape hammer (Fig. 3b).

2- An area of impact is three levels, a- 480 $\mathrm{mm}^{2}$, b- $720 \mathrm{~mm}^{2}$ and c- $960 \mathrm{~mm}^{2}$

$$
\mathrm{A}_{\mathrm{t}}=\mathrm{b} \times \mathrm{L}
$$

Where,

$A_{t}$, An area of impact face of the traditional hammer fig (4)

$\mathrm{A}_{\mathrm{T} \text {-shape }}=\left(\mathrm{I}_{1} \times \mathrm{b}\right)+\left(\mathrm{I}_{2} \times \mathrm{B}\right)$

Where,

A T-shape, An area of impact face of the Tshape hammer

$\mathrm{I}_{1}, \mathrm{I}_{2}, \mathrm{~B}, \mathrm{~b}$, it shows in fig. (5)

3- Feeding rate is two levels, a- $1500 \mathrm{~g} \mathrm{~min}^{-}$ 1 b- $3000 \mathrm{~g} \mathrm{~min}^{-1}$

Indicators and metrics of success were studied.

\section{Mill production capacity}

After running the mill for one minute and stopping it with an electronic timing regulator linked to the mill motor, the crushed grains were collected and weighed with an electronic scale. The following equation was utilized to 
quantify the mill production capacity $\left(\mathrm{g} \mathrm{min}^{-1}\right)$ (Basiouny \& El-Yamani, 2016).

$$
\mathrm{MPC}=\frac{W G}{\mathrm{~T}}
$$

Where,

MPC, Mill Production Capacity (g. $\left.\min ^{-1}\right)$

WG, weight of grains after the grinding (gram)

$\mathrm{T}$, the time of grinding(minute)

\section{Specific energy consumption}

The specific energy consumption requirement was calculated by using the equation 4 (Ibrahim et al., 2019).

$$
\text { Spec. }=\frac{C P}{M P C}
$$

Where,

Spec., Specific energy consumption (kw h $\mathrm{kg}^{-1}$ )

$\mathrm{Cp}$, Consumed power $(\mathrm{kw})$, it Calculated from equation 3

$$
\mathrm{Cp}=\frac{I . V \eta \cos \theta}{1000}
$$

Where,

I= line current strength (Amperes).

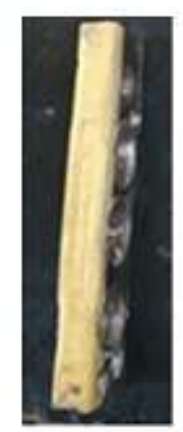

a

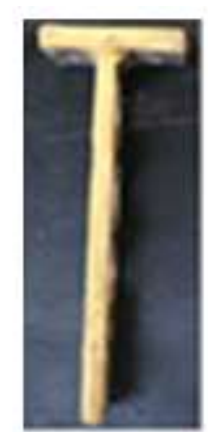

b
$\mathrm{V}=$ Potential strength (voltage) being equal to $220 \mathrm{~V}$.

$\operatorname{Cos} \theta=$ power factor (being equal to 0.84 ).

$\eta=$ Mechanical efficiency assumed (85\%).

\section{Results \& Discussion}

The effect of hammer's shape, impact area and interference on mill Production Capacity $\mathrm{g} \mathrm{min}^{-1}$ ( $1500 \mathrm{~g} \mathrm{~min}^{-1}$ of feed rate).

Table (2) that shows the results of the experiment related to the data of the hammer shape and the area of influence when using a feed rate of $1500 \mathrm{~g} \mathrm{~min}^{-1}$ (incomplete loading of the mill capacity) there is a significant effect $(p \leq 0.05)$ of the hammer shape on the production capacity of the mill, as the Tshape's hammer recorded 735. $78 \mathrm{~g} \mathrm{~min}^{-1}$ compared to the Rectangular Hammer, which recorded $613.05 \mathrm{~g} \mathrm{~min}^{-1}$. The reason may be due to the better distribution of the dimensions of the t-shaped hammer compared to the rectangular shape one and possibly the lower impact area under the conditions of incomplete loading of the mill chamber (feed rate $1500 \mathrm{~g} \mathrm{~min}^{-1}$ ). Moreover the results showed a significant effect in the opposite direction of the impact area on the mill's production capacity

(Fig.

$6)$.

Fig. (3): a and b: Hammer's shape. 

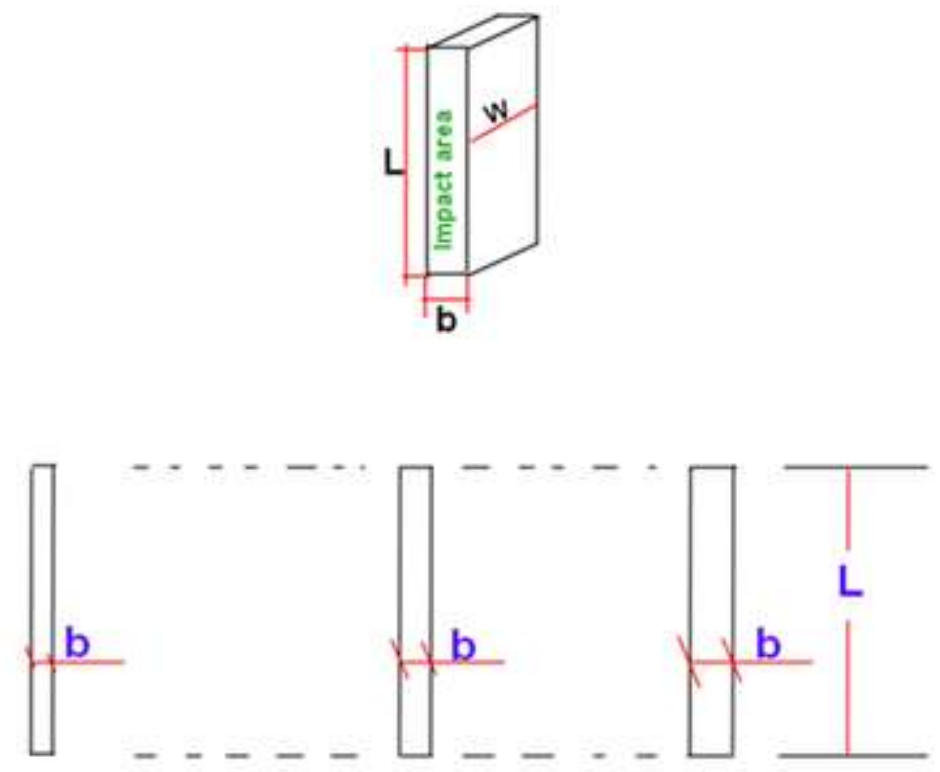

$$
480 \mathrm{~mm}^{2} \quad 720 \mathrm{~mm}^{2} \quad 960 \mathrm{~mm}^{2}
$$

Fig. (4): Levels of impact area of traditional hammer
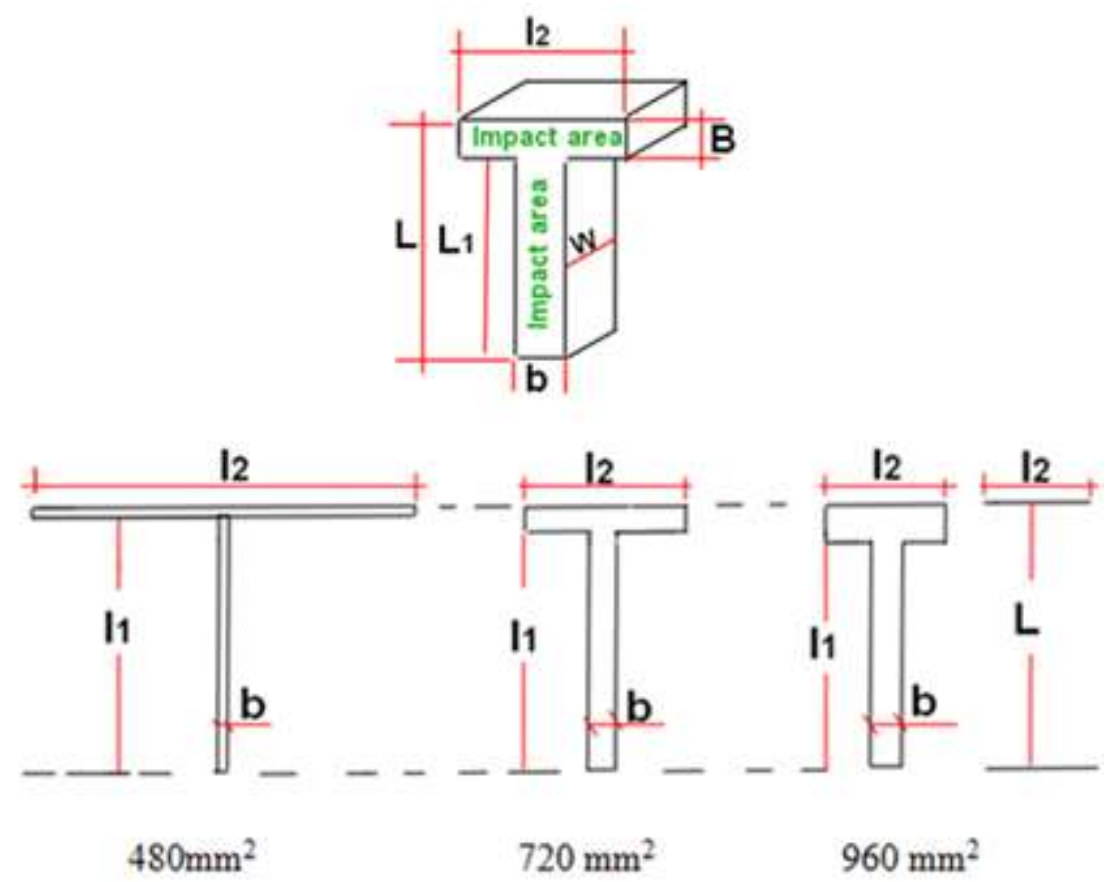

Fig. (5): Levels of impacts area of the T-shape hammer.

The capacity decreased by increasing the area of impact. The $480 \mathrm{~mm}^{2}$ area recorded the highest production capacity of $787.23 \mathrm{~g} \cdot \mathrm{min}^{-1}$ compared to the $720 \mathrm{~mm}^{2}$ and $960 \mathrm{~mm}^{2}$ area which recorded 684.075 and 551.95 g. $\mathrm{min}^{-1}$, respectively. While it showed no significant effect of interference shape and area of impact of the hammerThis result may be due to a 
decrease in the amount of surface area of the grains due to a decrease in the effective hammer surface area, and consequently the pressure on the grains becomes greater, which leads to an increase in grinding (Budacan \& Deac, 2013).

The effect of hammer's shape, impact area and interference on Specific energy consumption kw h kg-1 (1500 g.min-1 of feed rate).

The results of the experiment with the shape of the hammer and the area of impact shown in table (3). There is no significant effect $(p \leq 0.05)$ for the shape of the hammer and the interference on the specific energy consumption, while there is a significant effect of the affected area on the specific energy consumption of the mill operating. Area 480 $\mathrm{mm}^{2}$ recorded the lowest specific energy consumption of $0.03 \mathrm{kwh} \mathrm{kg}^{-1}$ compared with $0.04 \mathrm{kwh} . \mathrm{kg}^{-1}$ and $0.05 \mathrm{kwh} . \mathrm{kg}^{-1}$ for the area $720 \mathrm{~mm}^{2}$ and $960 \mathrm{~mm}^{2}$, respectively. This result represents a relative increase (per one $\mathrm{kg}$ of production capacity) and therefore the reason for its appearance is due to the relative increase in the production capacity of the mill resulting from the use of the $480 \mathrm{~mm}^{2}$ area as it show from the results of table (2).

Table (2): Effect of hammer's shape, impact area and interference on mill Production Capacity $\mathrm{g} \mathrm{min}^{-1}\left(1500 \mathrm{~g} \mathrm{~min}^{-1}\right.$ of feed rate).

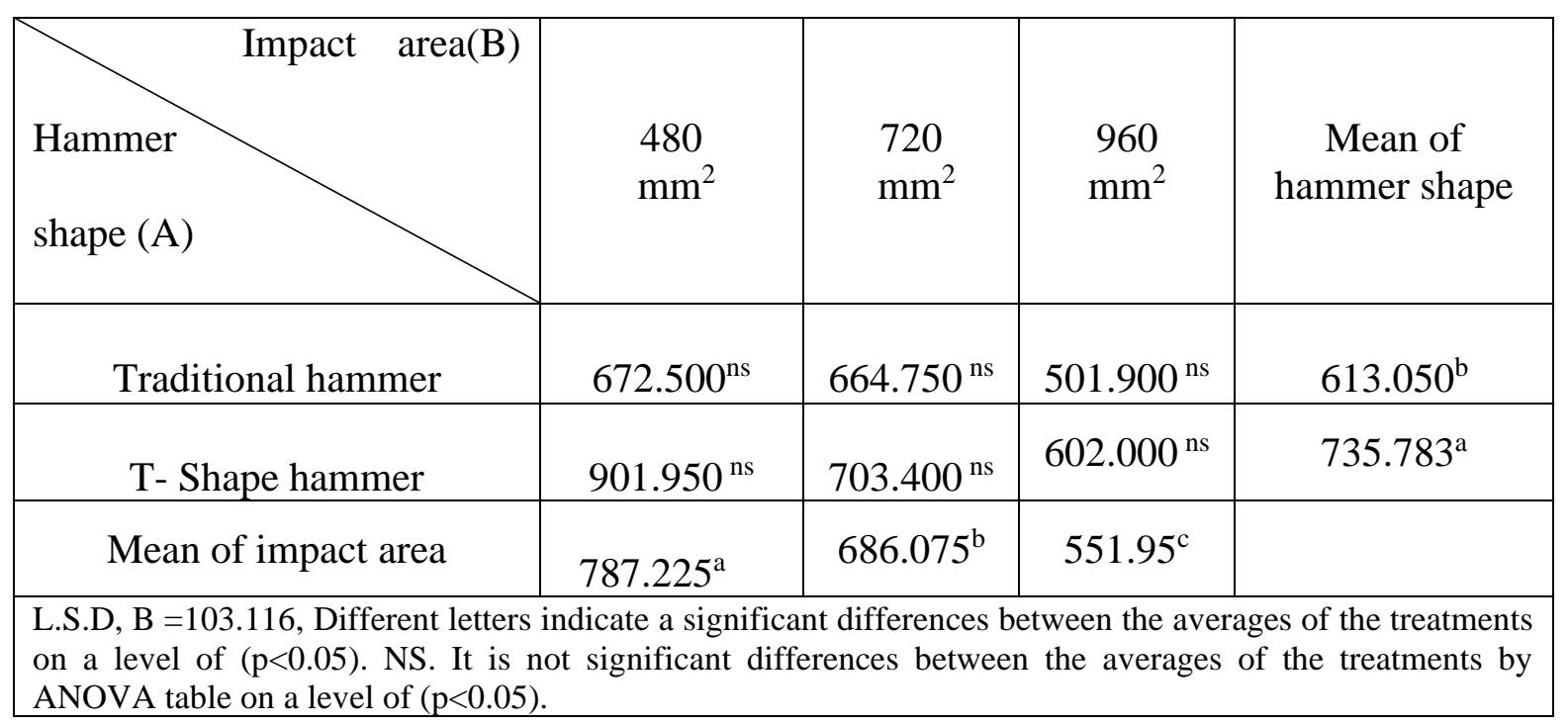




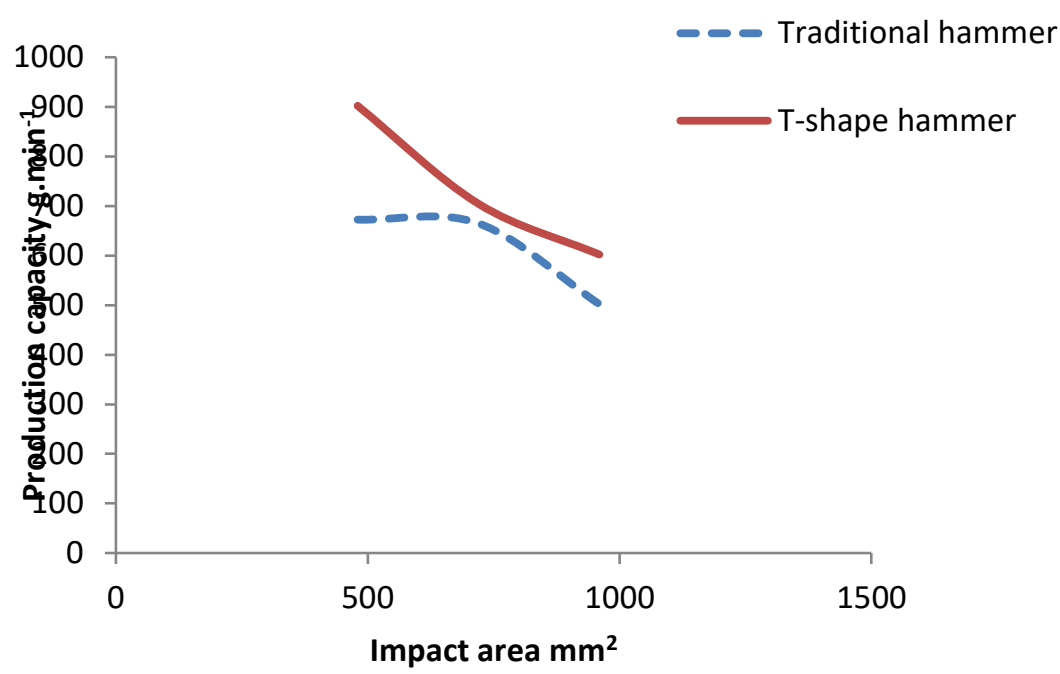

Fig. (6): Relationshipe between the impact area and production capacity.

Table (3): Effect of hammer's shape, impact area and interference on specific energy consumption kw.h.kg-1 (1500 $\mathrm{g} \mathrm{min}^{-1}$ of feed rate).

\begin{tabular}{|c|c|c|c|c|}
\hline shape (A) & $\begin{array}{l}480 \\
\mathrm{~mm}^{2}\end{array}$ & $\begin{array}{l}720 \\
\mathrm{~mm}^{2}\end{array}$ & $\begin{array}{l}960 \\
\mathrm{~mm}^{2}\end{array}$ & $\begin{array}{c}\text { Mean of } \\
\text { hammer shape }\end{array}$ \\
\hline $\begin{array}{c}\text { Traditional } \\
\text { hammer }\end{array}$ & $0.037^{\mathrm{NS}}$ & $0.039^{\mathrm{NS}}$ & $0.050^{\mathrm{NS}}$ & $0.042^{\mathrm{NS}}$ \\
\hline T- Shape hammer & $0.028^{\mathrm{NS}}$ & $0.036^{\mathrm{NS}}$ & $0.041^{\mathrm{NS}}$ & $0.035^{\mathrm{NS}}$ \\
\hline $\begin{array}{c}\text { Mean of impact } \\
\text { area }\end{array}$ & $0.033^{\mathrm{b}}$ & $0.037^{\mathrm{b}}$ & $0.046^{\mathrm{a}}$ & \\
\hline
\end{tabular}


Effect of hammer's shape, impact area and interference on mill Production Capacity g. $\mathrm{min}^{-1}$ ( $3000 \mathrm{~g} \mathrm{~min}^{-1}$ of feed rate).

Table (4), one note that the hammer shape has no significant effect on the production capacity of the mill at the feed rate of $3000 \mathrm{~g}$. $\mathrm{min}^{-1}$. The reason for this result may be due to the equalization and full utilization of the impact area. On the other hand there is an effect of the influence area on the mill capacity. The impact area exceeds $720 \mathrm{~mm}^{2}$ over the area $840 \mathrm{~mm}^{2}$ and $960 \mathrm{~mm}^{2}$, where it recorded $1215.7 \mathrm{~g} \mathrm{~min}^{-1}$ compared to 750.7 and $882.7 \mathrm{~g} \mathrm{~min}^{-1}$ respectively, therefore we find from Figure 7 an exponential relationship (non-linear) between the impact area and the displacement of the mill. This may be due to the effectiveness of this area $\left(720 \mathrm{~mm}^{2}\right)$ in the working area inside the $10 \mathrm{~cm}$ wide grinding chamber. Heimann (2019) confirmed this relationship as well.
Effect of hammer's shape, impact area and interference on Specific energy consumption $\mathrm{kw} \mathrm{h} \mathrm{kg-1}$ (3000 $\mathrm{g} \mathrm{min}^{-1}$ of feed rate)

The results in table (5) show no significant effect of hammer shape, as well as the interference between shape and hammer area on the specific energy consumption. While there is a clear impact on the impact area, as the area $720 \mathrm{~mm}^{2}$ recorded the lowest specific consumption of operational energy, amounting to $0.021 \mathrm{kw} \mathrm{h} \mathrm{kg}{ }^{-1}$ compared to 0.027 and $0.029 \mathrm{kw} \mathrm{h} \mathrm{kg}^{-1}$ for area 840 and $960 \mathrm{~mm}^{2}$, respectively. The reason for this result is that the hammer has an area of $720 \mathrm{~mm}^{2}$ in the production capacity, so the negative energy consumption appears, this can be explained by the fact that the impact area, when reduced, leads to a decrease in energy requirements.

Table (4): Effect of hammer's shape, impact area and interference on mill production capacity $\mathrm{g} \mathrm{min}^{-1}\left(3000 \mathrm{~g} \mathrm{~min}^{-1}\right.$ of feed rate).

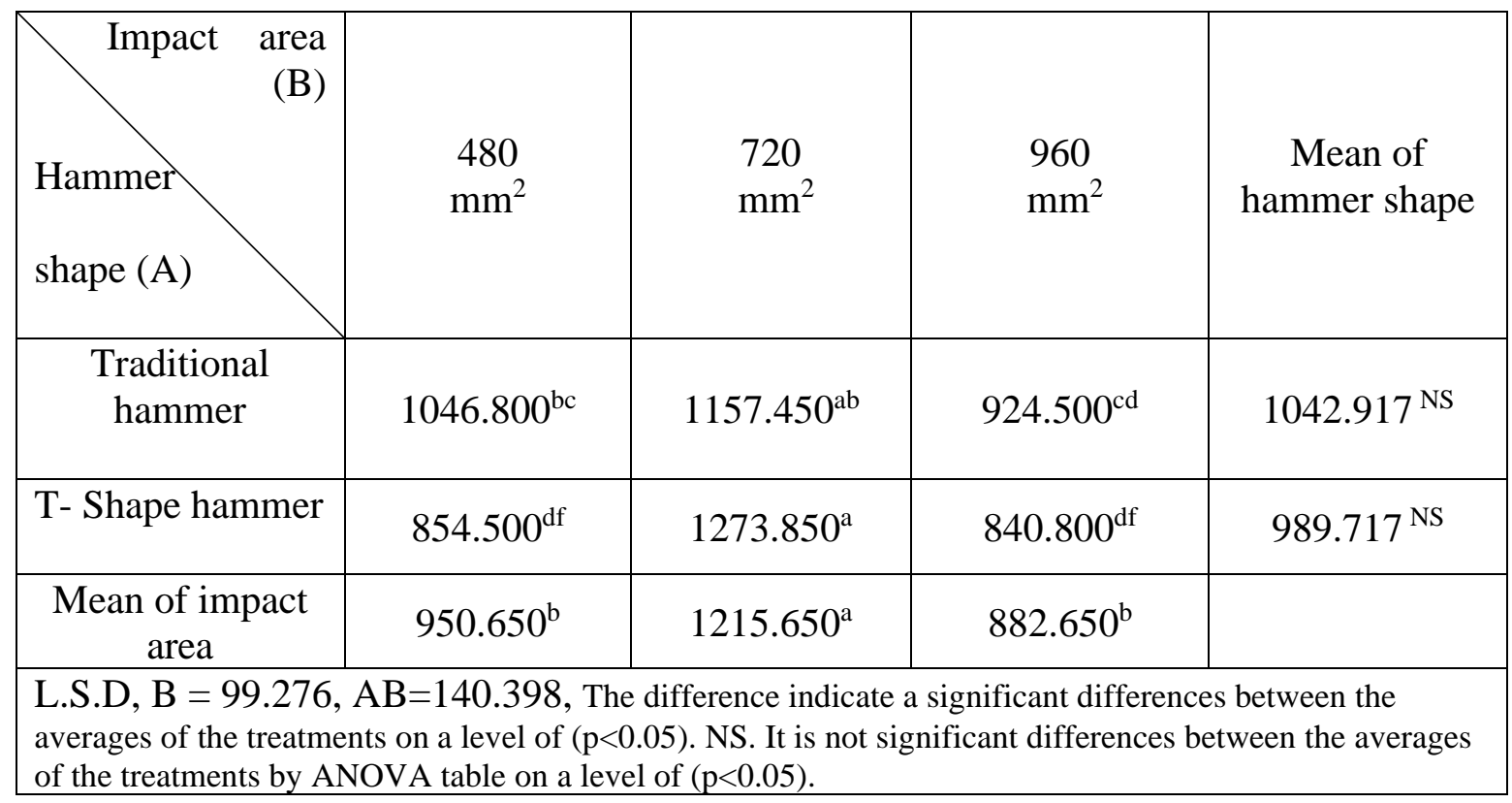




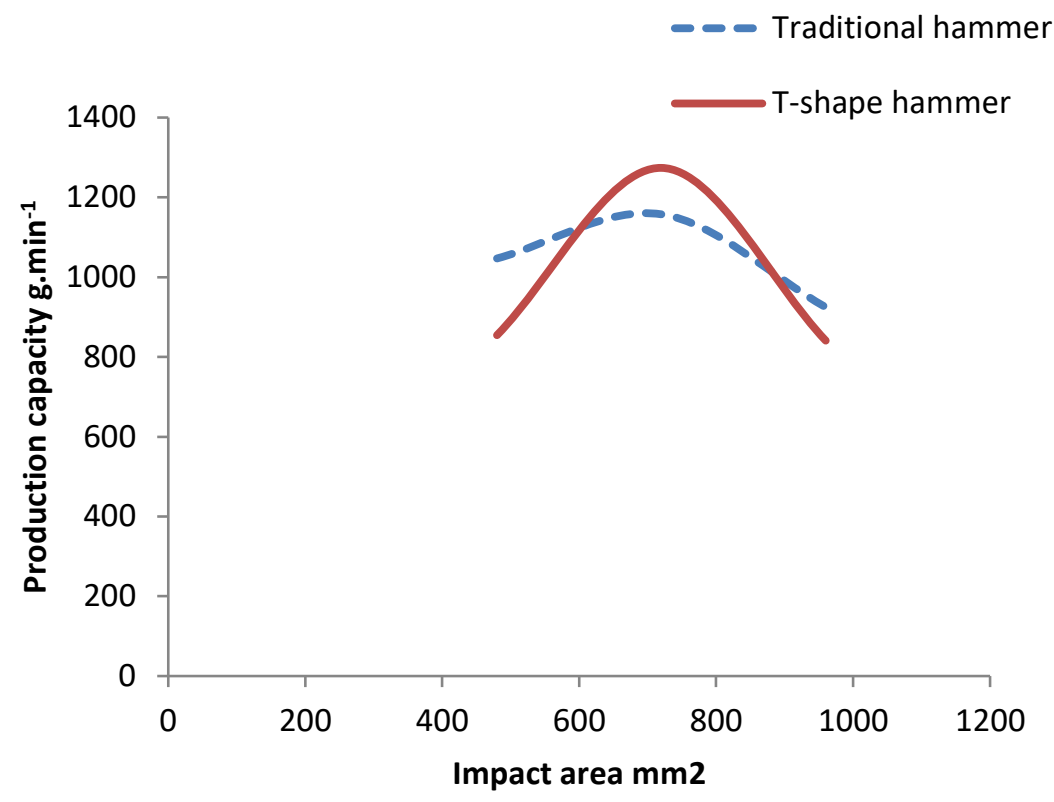

Fig. (7): relationshipe between the impact area and production capacity at $3000 \mathrm{~g} \cdot \mathrm{min}^{-1}$.

Table (5): Effect of hammer's shape, impact area and interference on specific energy consumption $\mathrm{kw} \mathrm{h} \mathrm{kg-1}\left(3000 \mathrm{~g} \mathrm{~min}^{-1}\right.$ of feed rate).

\begin{tabular}{|c|c|c|c|c|}
\hline $\begin{array}{r}\text { Impact } \begin{array}{r}\text { area } \\
\text { (B) }\end{array} \\
\text { shape (A) }\end{array}$ & $\begin{array}{c}480 \\
\mathrm{~mm}^{2}\end{array}$ & $\begin{array}{c}720 \\
\mathrm{~mm}^{2}\end{array}$ & $\begin{array}{c}960 \\
\mathrm{~mm}^{2}\end{array}$ & $\begin{array}{c}\text { Mean of } \\
\text { hammer shape }\end{array}$ \\
\hline $\begin{array}{c}\text { Traditional } \\
\text { hammer }\end{array}$ & $0.024^{\mathrm{ns}}$ & $0.022^{\mathrm{ns}}$ & $0.027^{\mathrm{ns}}$ & $0.024^{\mathrm{NS}}$ \\
\hline $\begin{array}{c}\text { T- Shape hammer } \\
\text { Hammer }\end{array}$ & $0.030^{\mathrm{ns}}$ & $0.019^{\mathrm{ns}}$ & $0.030^{\mathrm{ns}}$ & $0.026^{\mathrm{NS}}$ \\
\hline $\begin{array}{c}\text { Mean of impact } \\
\text { area }\end{array}$ & $0.027^{\mathrm{a}}$ & $0.021^{\mathrm{b}}$ & $0.029^{\mathrm{a}}$ & \\
\hline $\begin{array}{l}\text { L.S.D, B }=0.003 \\
\text { of the treatments on a level of }(\mathrm{p}<0.05) \text {. NS. It is not significant differences between the averages of the } \\
\text { treatments by ANOVA table on a level of }(\mathrm{p}<0.05) .\end{array}$ \\
\hline
\end{tabular}

The effect of feeding rate on the production capacity of the mill

Fig. (8) shows a significant effect of the feeding rate on production capacity. The feed rate $3000 \mathrm{~g} \mathrm{~min}^{-1}$ recorded the highest milling capacity of 1042.9 g. $\mathrm{min}^{-1}$ and 991 g. $\mathrm{min}^{-1}$ for the T-shape hammer and the rectangular hammer respectively compared with the feed rate $1500 \mathrm{~g} \mathrm{~min}^{-1}$ for the 737.03 g. min $^{-1}$ T-shape hammer and the 316.07 g. $\mathrm{min}^{-1}$ rectangular hammer. The reason for this result may be due to the full 
utilization of the impact area of the hammers when using a high feed rate $(3000$ g. $\mathrm{min}^{-1}$ ). The results of several researchers have shown an increase in the capacity of the mill with an increase in the feeding rate, as researcher (Dabbour et al., 2015; Ibrahim et al., 2019).

\section{The effect of feeding rate on the specific energy consumption of the mill}

The results of the experiment on the effect of feed rate on specific energy consumption are shown in fig. (9). There is a significant effect $(p \leq 0.05)$ of feed rate on specific energy consumption. Feed rate 3000 g. $\mathrm{min}^{-}$ recorded the lowest specific energy consumption of 0.024 and $0.027 \mathrm{kwh} . \mathrm{kg}^{-1}$ compared with 0.042 and $0.035 \mathrm{kw} \mathrm{h} . \mathrm{kg}^{-1}$ for the T-hammer and the rectangular hammer, respectively when using the rate of nutrition $1500 \mathrm{~g} \cdot \mathrm{min}^{-1}$. The reason is due to the relative increase in the production capacity of the mill resulting from the use of a feed rate higher than 1500 g. $\mathrm{min}^{-1}$, As well as Ibrahim et al. (2019) found the decrease in the consumption power of the mill with an increase in the feeding rate

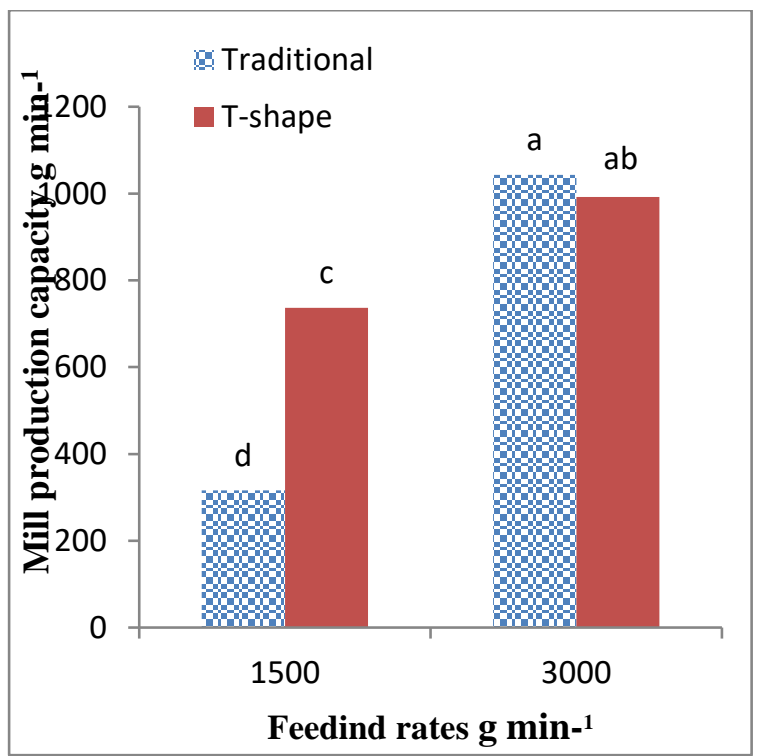

Fig. (8): Comparison of the effect of feed rate rates 1500 and 3000 on mill capacity.

\section{Conclusions \& Recommendations}

1-There is a significant effect of hammer shape on the production capacity at a feed rate of $1500 \mathrm{~g} \mathrm{~min}^{-1}$. While there is no such effect on the shape of the hammer on the production capacity at a feed rate of 3000 g.min ${ }^{-1}$.

2- There is a significant effect of the influence surface area on the production capacity and

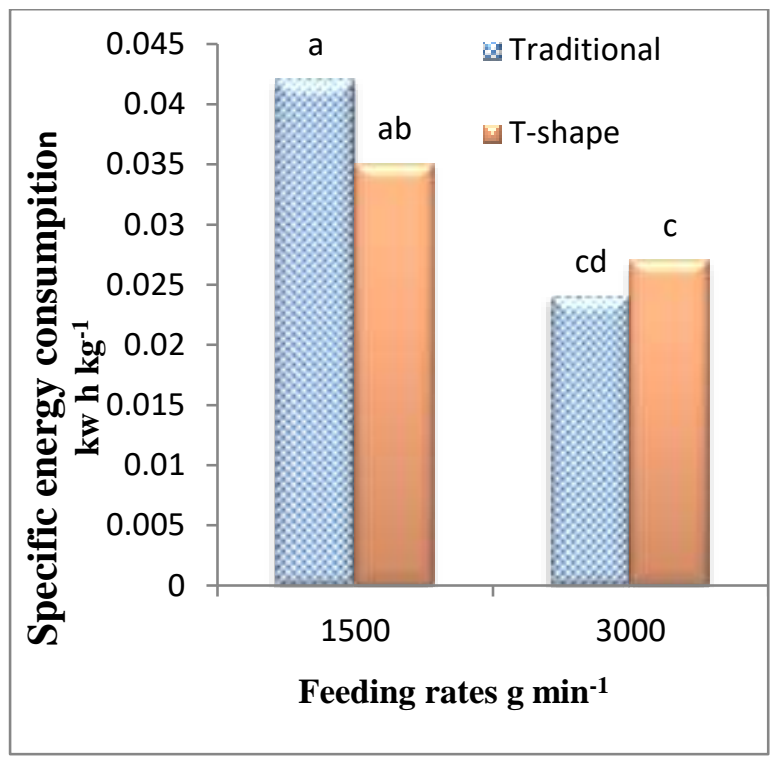

Fig. (9): Comparison of the effect of feed 1500 and 3000 on Spc.

specific energy consumption at the feed rate of 1500 and $3000 \mathrm{~g} \mathrm{~min}^{-1}$.

3- There is an inverse relationship between the impact area and the mill production capacity at the feed rate 1500 g.min ${ }^{-1}$, while there is a non-linear relationship between them at the feed rate 3000 g. min $^{-1}$ 
4- There is a significant effect of feed rate on and the mill production capacity and specific energy consumption.

5- The T-shape hammer can be used at low feed rate (in which the impact area is not fully utilized).

6- It is preferable to use a traditional hammer when the impact area is fully utilized by using a high feed rate of 3000 g.min ${ }^{-1}$ for its high performance compared to the $\mathrm{T}$-shape hammer as well as for simplicity of design and manufacturing.

\section{Acknowledgments}

The authors appreciate Dr. Kazem H. Hadhili of Department of Field Crops, College of Agriculture, University of Basrah for assistance in updating the statistical analysis of current work.

\section{References}

Ali, M. A., Ali, A., Abbas, B. A., \& Abdul Lateef, Z. A. (2019). Study and evaluation of the process of grinding the yellow maize grains by using chains for locally developed hammer mill. Plant Archives, 19 , 1887-1892. http://www.plantarchives.org/PDF\%2019-1/18871892\%20(4895).pdf

Basiouny, M. A., \& El-Yamani, A. E. (2016). Performance evaluation of two different hammer mills for grinding corn cobs. Journal of Soil Science. and Agricultural .Engineering, Mansoura University, $7, \quad 77-87$. https://doi.org/10.21608/JSSAE.2016.39322

Budacan, I. \& Deac, I. (2013). Numerical Modeling of CFD model Applied to a Hammer Mill.. Napoca Agriculture, 70, 273-282. https://doi.org 10.15835/buasvmcn-agr:9338

Dabbour, M., Bahnasawy, A. S., \& El-Haddad, Z. (2015). Grinding parameters and their effects on the quality of corn for feed processing. Journal of Food Process Technology, 6, 482-488. https://doi.org 10.4172/2157-7110.1000482

Djuro, M. V., Levic, J. D., Aleksandar, Z. F., Radmilo, R. C., Brlek, T. I., Dusica, S. C., \& Olivera, M. D. (2016). Influence of grinding method and grinding intensity of corn on mill energy consumption and pellet quality. Hemijska Industrija, 70, 67-72. https://doi.org/10.2298/HEMIND141114012V

Heimann, M. (2019). Feed pelleting reference guide, section 3: Manufacturing consideration, chapter 10: Grinding consideration when pelting livestock feeds. N.C. State university. 18pp. https://www.feedstrategy.com/wpcontent/uploads/2019/09/3-

10_Grinding_considerations_when_pelleting_lives tock_feeds.pdf

Ibrahim, M., Omran, M., Abd El-Rahman, E. N. (2019). Design and evaluation of crushing hammer mill. Misr Journal of Agricultural Engineering, 36, 124. https://doi.org/10.21608/MJAE.2019.94437

Mircea-Valentin, M., Marian; O., Ranta, O., Drocas I., \& Catunescu M. G. (2013). The influence of hammer type used in grinding mills on grist fineness. Bulletin UASVM Food Science and Technology 70, 53-57. https://doi.org/10.15835/buasvmcn-fst:9355 .

Oluwole, F. A., Gujja, A., \& Abubakar, A. K. (2019). Effect of number of beaters on the performance of household hammer mill. AZOJETE, 15, 619-627. https://www-.academia.edu/41838974

Satoshi, A., Kozawa, K., \& Yoshida H. (2004). Effect of blade angle on pulverizing characteristics in a mechanical impact mill: Calculation of particle trajectory for a long simulation time. Kagaku kogaku ronbunshu 29, 607-613. https://doi.org/ 10.1252/kakoronbun-shu.30.108

Shirshaab, A. J., \& Jassim, J. M. (2021). effect of adding different levels of Portulaca oleracea L. seeds and leaves powder to the diet on productive and physiological performance of broiler chickens (Ross308). Basrah Journal of Agricultural Sciences, 34, 38-48. https://doi.org/10.37077/25200860.2021.34.1.04. 
تأثير شكل المطرقة ومساحة تأثير سطح الصدم على اداء المجرشة المطرقية تحت معدلات تغذية مختلفة

\author{
اسعد يوسف خضير، سالم عجر المالكي وماجد صالح حمود \\ قسم المكائن و الات الزر اعية، كلية الزراعة، جامعة البصرة، العراق
}

المستخلص: يهدف البحث إلى مقارنة السعة الانتاجية (PC) واستهلاك الطاقة النوعي (Spc) للمجرشة المطرقية من خلال استخدام المطرقة شكل حرف T مقابل المطرقة المستطيلة (التقليدية). تم استخدام مجرشة محلية الصنع بأربع

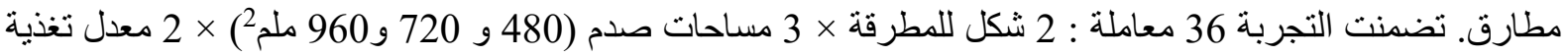

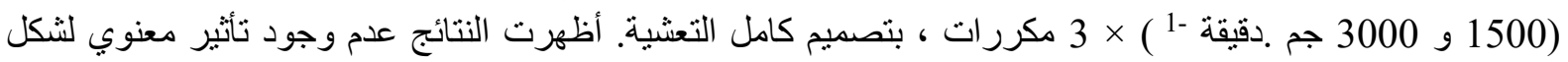

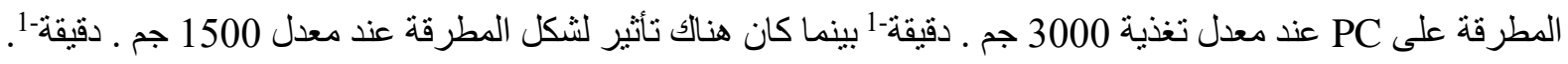

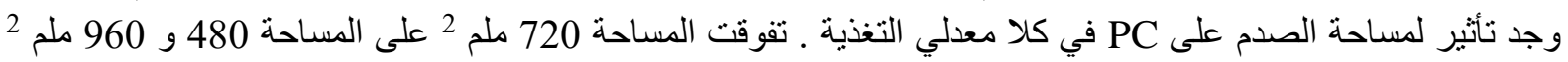
عند معدل تغذية 3000 جرام .دقيقة -1 حيث سجلت 1215.65 جر ام. دقيقة -1 مقابل 1 مائل

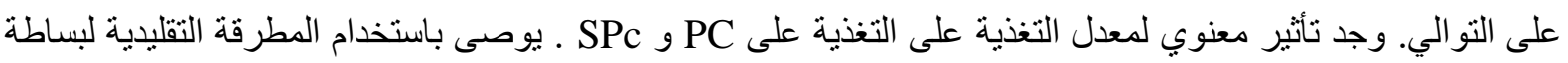

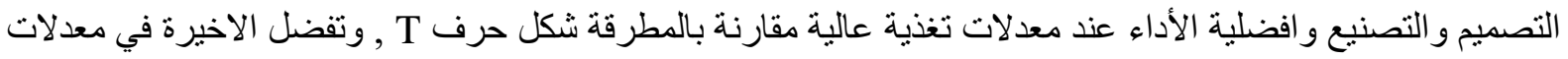
التغذية المنخفضة. الكلمات المفتاحية: الطحن، قوة الصدم، سعة المطنة، استهلاك الطاقة النوعي، شفرة المطحنة، معدل التدفق. 